\title{
TECTONIC CAVES OF SOLAI IN THE KENYAN RIFT VALLEY
}

\author{
Robert A. Davis *
}

ABSTRACT

\begin{abstract}
Tectonic caves at Solai, Kenya, were explored in 1970. These lie in a complex geological area of the Great Rift Valley in columnar-faulted Ignimbrite. Fissures are presumed to have been widened by later tectonic activity e.g. the major eathquake of January, 1928. The caves and exploration are briefly described. Questions of formation, drainage and possibilities of steam reservoirs are discussed.
\end{abstract}

Keywords: vulcanospeleology, tectonic caves, Rift Valley, Kenya

\section{INTRODUCTION}

In 1969 - 70, the CEGEA ${ }^{1}$ explored tectonic fissures around Nakuru in Kenya's Rift Valley. Nakuru is a strategically placed market town $160 \mathrm{~km}$ north of Nairobi. Immediately to the north of this township with its famous flamingo lake, lies the large caldera of Menengai. The caves described lie $7 \mathrm{~km}$ further north at $0-^{\circ} 4^{\prime} \mathrm{S}, 36^{\circ} 6.5^{\prime} \mathrm{E}$.

At that time the cave area was owned by two European farmers, "Lofty" Reynolds and Dick Milton. Their farms lay in a $4 \mathrm{~km}$ wide graben at the foot of an escarpment that rises steeply from 6000' to Lolderodo summit at 9400'. A railway siding ran from Nakuru. The agriculture was coffee and mixed farming, with cattle ranching on the valley floor. In those days, wild animals were not rare. Several different tribes of local people could be found, both as farmers and farm workers. The rainfall varies from $160 \mathrm{~cm}$ down to $90 \mathrm{~cm}$ p.a. at the valley floor. There was a small lake, Solai, and the Ol Punyatta swamp. Three small rivers drained east - west. Both the Tinderess and Watkins rivers soaked away on the farms. Only the Olobainita made it to the Ol Punyatta swamp, cutting tunnels on its way through the soft Tuff further downstream. A few kilometres to the north, on Horst Von Kaufmann's farm, all the bore-holes bore continual warm water. Several seasonal hot springs lay along the base of the Solai escarpment.

The geology is extremely complicated. Since the Miocene, each volcanic outpouring has been succeeded by movement, normal faulting compatible with distension of the crust. Menengai has Recent, blocky, black Trachite flows which have not yet succumbed to vegetation. No outcrops of the underlying crystalline rock have been found. The amazing topography of this area includes a textbook example of fault scarps, a magnificent flight of thirteen 'steps' up the Bahati escarpment. The major Lolderodo fault lies along the length of this escarpment. Thirty $\mathrm{km}$ to the north, and 3000' lower, lies Lake Bogoria (called Hannington at that time) which has active fumaroles and boiling hot springs. The farms mentioned are situated on Tuffs with a volcanic soil overlay. The two major Tuffs are a soft, reddish brown, unstratified Lapilla ("Solai") Tuff from the Upper Pleistocene, and an "Ignimbrite" - a welded Tuff dating from the Pliocene.

\footnotetext{
" Member of CEGEA. Now at Telemark College, Norway.

1 Cave Exploration Group of East Africa.
} 


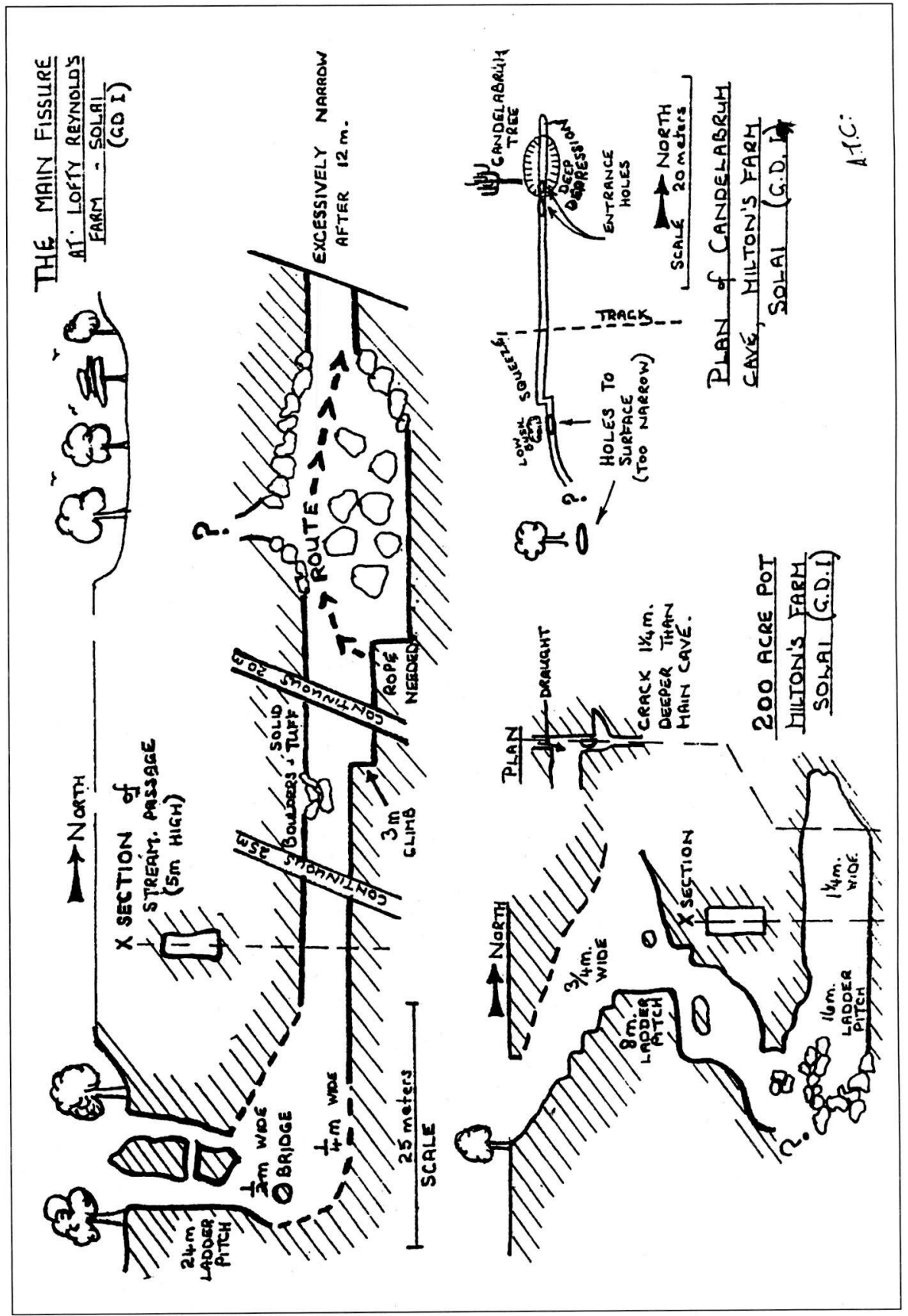

Fig. 1a - The main fissure at Lofty Reynold's farm, Solai (GD I). Fig. 1b - 200 acre pot, Milton's farm, Solai (GD I).

Fig. 1c - Plan of Candelarum Cave, Milton's farm, Solai (GD I). 
According to our field notes written at the time, the Lapilla Tuff contained "blebs of obsidian and a honeycomb stone" - presumably a pumice - and the Ignimbrite had a "laminar texture".

The Solai Ignimbrite was almost certainly laid down in an overland flow. Presumably, its columnar faulting occurred during cooling and was enlarged by later tectonic activity. For example, in 1926 \& 1928 there were sizeable earthquakes. The one in January ' 28 had its epicentre near Bogoria and was measured at 7.0 on the Richter scale. A reliable resident ${ }^{2}$ at the time told that a $6 \mathrm{~m}$ high $300 \mathrm{~m}$ long scarp of Lapilla tuff appeared after the 'quake, and that the three rivers went underground, and that both the Ol Punyatta swamp and Solai lake shrank considerably. Also, it is recorded ${ }^{3}$ that a $2 \mathrm{~m}$ wide crack opened up at the bottom of the escarpment, just S of Lake Bogoria ${ }^{4}$.

With the thirteen fault scarps to the east and the Menengai crater to the south, it is not surprising that tectonic caves occur here. Although (unlike the nearby Lake Naivasha) Lake Nakuru is not an old caldera, Menengai could well be the centre of a radial stress pattern which complicates the geological picture even more.

\section{THE CAVES}

The caves explored are marked on the geological map as "fissures". In that area some 37 depressions were found, all lying N-S in two parallel lines about 70m apart, over a length of a kilometre. These depressions varied from 1 to $4 \mathrm{~m}$ deep. About thirteen of these opened into fissures. Several were fenced off, presumably to prevent accidents. Only one of those fenced was still open. This might indicate their changing state.

Nakuru district abounds with stories about the ground opening up. One such tells of a Boer who coupled six oxen together to pull his tractor out. In Solai, both farmers told of cows falling down. And even that this poor beast could be heard for some time after - apparently walking to other fissures (something which seems most unlikely in practice). It was also reported that two workers digging a well had disappeared. This shaft was later used as a very 'long-drop' toilet but proved unsuitable because of the strong updraughts.

All the explored fissures had narrow entrances in Solai Tuff. None of these entrances were particularly large. They were as much 'shafts' as 'fissures'. Lower down, however, they were definitely fissures. Most were in the Solai Tuff for at least $6 \mathrm{~m}$ depth, and descended into the Ignimbrite where the hard, parallel walls of the welded Tuff showed some signs of water transport. They were up to $25 \mathrm{~m}$ deep, $1.3 \mathrm{~m}$ wide, and $125 \mathrm{~m}$ long (Fig. 1). The height of the lower passages sometimes increased in steps, by as much as $3 \mathrm{~m}$. This says something about the way the Ignimbrite cracks up. Also, as might be expected, there were sometimes transverse cracks running E-W at the end of a fissure. The widest found was $20 \mathrm{~cm}$ and carried a draught.

No artefacts were noted, although mummified remains of cow, deer, dog \& hare were found (Fig. 2). The ill-fated well-shaft was not descended further than one ladderlength because of the smell - but it was plumbed deeper than $30 \mathrm{~m}$. In one case there was noted a difference in vertical displacement between matching features on opposite fissure walls. All of the explored fissures ran N-S and were vertical. However, one very narrow extension was tilted from the vertical and appeared to swing out of the N-S line.

\footnotetext{
2 Colonel Sam Reeder.

3 Tilloston, 1937.

4 In our explorations in 1970 , this crack appeared to have become almost filled with soil.
} 


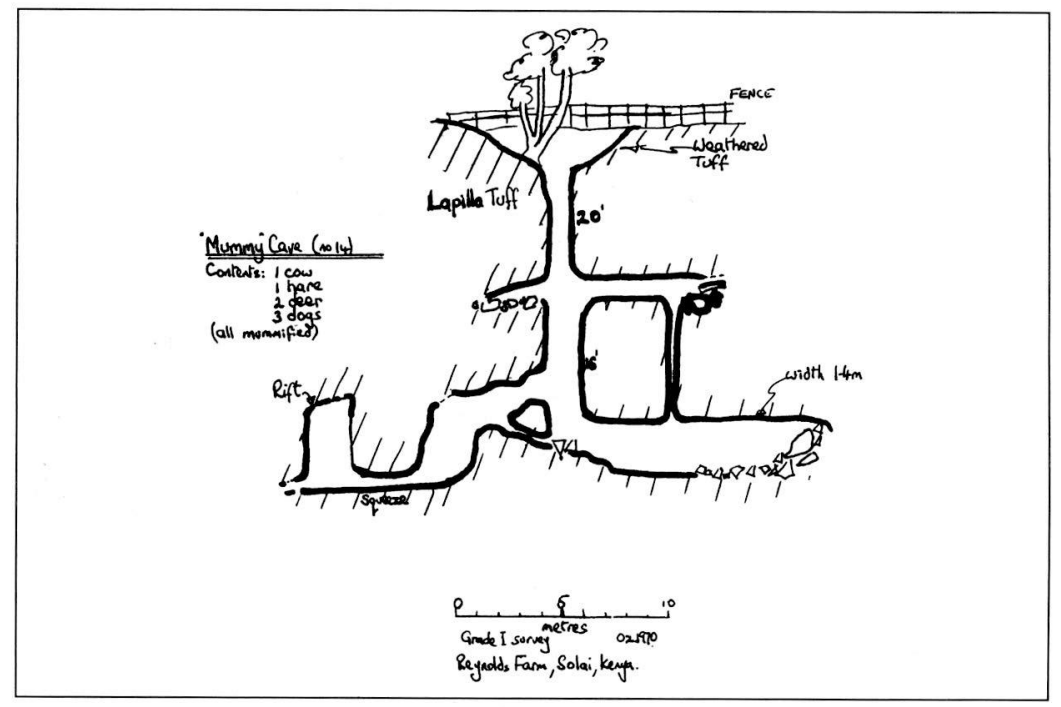

Fig. 2 - "Mummy" Cave (Contents: 1 cow, 1 hare, 2 deer, 3 dogs - all mummified).

These caves required a degree of climbing skill, and some needed ladders. From a caving point of view they were "sporting". Explorers in African caves should be aware of the dangers of caving and of low lying carbon dioxide.

\section{DISCUSSION}

1) Presumably these fissures originate in the natural columnar faulting of the Ignimbrite, much disrupted by later faulting due to tectonic fragmentation of the crust for example, during the earthquakes of '26 and '28; (later earth tremors have also been recorded. ${ }^{5}$ ) However, the height variations in some of the explored fissures suggest a more complex faulting than a simple columnar structure.

2) Without more evidence than we have from 1970, it might be that these fissures occur primarily in the Ignimbrite, entrance being made through the more plastic Solai Tuff by surface water and other mechanisms. Because "fissures" are marked on the 1959 geological map, and a dozen 'blind' depressions were fenced, it opens up discussion about whether these were more open at that time. And indeed, about whether these entrances could have been filled in by some mechanism - natural or otherwise - and whether they might reopen.

3) At the time of the original exploration a further shaft was explored and descended to $55 \mathrm{~m}$ on Nye Chart's farm in Njoro, west of Nakuru. This cave had appeared suddenly when a stream suddenly went underground. The soft Tuff rapidly disappeared into a hole which enlarged to $25 \mathrm{~m}$ in surface diameter, $55 \mathrm{~m}$ depth in less than a year. The farmer strung a cable across this and descent was made to a jammed tree 30m down - reputedly by a nine-year old!

Further significant enlargement did not occur afterwards. This raises the question of 
where could $10,000 \mathrm{~m}^{3}$ of soil go so easily? McCall (1957) observes that the drainage goes down through porous rock and fissures to the water table. Presumably, there is plenty of open space down there.

4) The most interesting question of "where does the water go?" could lead to much speculation. The signs of water transport - i.e. apparent vadose enlargement of some lower fissures - seemed to indicate that the water flowed away at speed. This would be as expected, of course.

5) At Ol Punyatta Station (at boreholes $131 \&$ C1066) the writer was informed of "considerable quantities of (low pressure) steam". Hot springs occur along the foot of the Solai escarpment near the Watkins Stream and several farms had warm water (at about $39^{\circ} \mathrm{C}$ ). These might be sourced by returned ground water, but the persistence in supply at Von Kaufmann's suggests sourcing from depth, as a shallow supply would be seasonal.

The steam jets and geysers at Lake Bogoria are sourced by hot juvenile $\mathrm{CO}_{2}$, according to the Geological report ${ }^{6}$. The same report suggests that there is no extensive, economically exploitable steam reservoirs in the area. The writer wonders if this is correct. At any rate, a good deal of water disappears somewhere. On the question of drilling for steam, however, the problem of unstable rock rises. It is necessary for both drill and borehole to be precisely near-vertical. Any shifting of the horizontal alignment is unacceptable. With the slight movements probable in the ground discussed, this would make drilling difficult, if not impossible. Not to mention the huge deformations which occurred in '28. However, the possibility should not be forgotten, and future technical developments might open up an energy source here in Solai.

At Olkaria some $70 \mathrm{~km}$ further south there is exploitation of a very substantial steam reservoir which is not being depleted as was originally estimated. The water has been traced not to come from the nearby Lake Naivasha, as originally assumed. The drilling goes down to $2200 \mathrm{~m}$ where the temperature is over $300^{\circ} \mathrm{C}$. The reservoir starts at $600 \mathrm{~m}$ depth. That describes a volume measured in cubic kilometres. As early as 1953, J. Scott suggested "immense quantities of steam trapped under an impervious cover". This idea seems very likely to the writer. It may not be necessary for this "cover" to be so very impervious, either. For example, it is possible for temperature inversions to occur in stable atmospheres. And fresh water can lie under salt water ${ }^{7}$. Similarly superheated water and steam could lie trapped beneath a cooler water body lying in the pervious/fissured rock above.

6) The question of how the Ignimbrite is laid down has certainly been thoroughly discussed, researched and described. The writer has little specific knowledge of this, but is speculating:-

In Solai we are talking about an overland flow. One presumes that the eruption was not so violent as to throw the particles into the air but appeared as a viscous outpouring. One assumes that this could have been from a central volcanic source, or from rifts. Gas charged lavas, sub-divided into particles enveloped in a tightlycompressed expanding gas, made up the flow. The gas was probably sourced mainly by continuous emission from the particles themselves - due to the sudden pressure reduction. This means that the eruption spews out 'exhaling' particles, a mix-

\footnotetext{
McCall 1967

7 Large quantities have been found under the Caribean, presumably from the Amazon. There has been some speculation as to whether the energy thus trapped could be harnessed; and also as to whether the unexpected release of such energy - for example, by a ship on the surface - could cause an explosive release of the fresh water which would destroy surface objects. - Personal communication from Norwegian pipelineconsultant Sivert Vaagen, Skien, Norway.
} 
ture of solids and fluids. The expanding gases act as a propellant which add to the effect of gravity alone. The escaping gases cause a great reduction in viscosity so that the flow might travel overland at great speed. The topography of the terrain delimits the flow's expansion until finally the particles are laid down, welded together into the Ignimbrite.

From this theoretical presumption one might expect to find a porous Tuff. As this is not the case one wonders why not. One suggestion might be that the particles varied from size-zero upwards, and thus packed into a solid rock when they were laid down, with the gas escaping upwards.

It would be interesting to experiment with models of this mechanism. For example, with particles of dry ice with heated iron-filings and ball-bearings.

\section{REFERENCES}

DAVIS, R.A. 1971 "Kenyan Rift Caves". The Second Bulletin of the Cave Exploration Group of east Africa

MCCALL G.J.H. 1967 "Geology of the Nakuru-Thompson's Falls-Lake Hannington Area". Geological Survey of Kenya.

MCCALL G.J.H. 1959 Geological map of the Nakuru Area. Geological Dept of Kenya.

MCCALL G.J.H. 1957 Geology and groundwater conditions in the Nakuru area. Technical report no 3. Ministry of Works (Hydraulic Branch) Kenya.

SCOTT J. 1953 The Great Rift Valley and it's economical Possibilities - private printing, Nairobi.

SUTCLIFFE A. 1973 Caves of the E. African Rift Valley. Transactions of The Cave Research Group of Gt Britain, Vol 15 no 1. pp 41-65. Feb'73

TILLOSTON E. 1937 The African Rift Valley Earthquake of Jan 6th, 1928. Royal Astronomical Society: Monthly notes, Geophysical supplement 4 pp 72-93.

TILLOSTON E. 1938 Further notes on the African Rift Valley Earthquake of Jan 6th, 1928. Royal Astronomical Society: Monthly notes, Geophysical supplement p 315. 